\title{
Integrative Aspects of Non-verbal Cultural Communication in Europe. Case Study - Pantomime
}

\begin{abstract}
This article touches on the integrative aspects of non-verbal cultural communication as exemplified by diverse pantomime genres in modern Europe. The starting point being the characteristic features of this form of art, as well as its genesis and functions in the Eastern and Western parts of the globe. Festivals, which have been rapidly developing in the world of pantomime and street art since the beginning of the 1970s, play an exceptional role in European cultural exchange. They are, however, generally ephemeral projects, often placed besides institutionalised mainstream culture, with no aspirations to become part of the EFA for example. Nonverbal cultural communication in Europe is still poorly integrated and yet maintains a remarkable diversity of genres and multi-colour forms. Such decentralisation is also the source of its strength manifested by its ease in reaching an incredibly diverse audience, the ability to obtain feedback from mass audiences, its expansiveness (taking up various spaces), its flexible approach in its quest for answers - but at the same time respecting the rudiments of the rich, native European tradition of popular culture. It seems that EU institutions nowadays notice the significant role of this type of intercultural communication, as evidenced by, for example, the Commissioner Gabriel's statement regarding a meeting with EFA representatives on $22^{\text {nd }}$ June 2021. The European Union has no harmonisation competences in the area of culture, but rather solely complementary and supporting functions with regards to Member States' activities - one can count on EU sectoral support funds from the Creative Europe Programme. The subsidisation of festival, confrontation, and meeting movements related to non-verbal cultural exchange can take place (and does take place) through regions, local governments, or cultural institutions.
\end{abstract}

Keywords: Non-verbal Communication, Cultural Communication, Pantomime, Mime Festivals, Street Art Festivals, Intercultural Communication, Europe

^ Mirella Kurkowska - University of Warsaw, e-mail: mkurkowska@uw.edu.pl, ORCID: 0000-0002-6289-7509. 
"If laughter and tears are the characteristics of humanity, all cultures are steeped in our discipline"

Marcel Marceau

\section{Introduction}

From the vantage point of convergence/integration processes or just cultural exchange, pantomime is an art with exceptional possibilities. Understood, in a broad sense, as a form of body-mimetic, non-verbal, improvised, body-based communication, and at the same time complex in terms of communication and semantics - in light of today's research, it is sometimes even considered a crucial stage in the evolution of human language (Michael Arbib, Michael Tomasello, Jordan Zlatev). ${ }^{1}$ What is more, according to the proponents of such concepts “(...) both naturalistic and experimental data suggest that the system of pantomime did not disappear and is actively used by modern humans. Its contemporary manifestations, or pantomimic fossils, emerge when language cannot be used, for instance when people do not share a common language, or in situations where the use of (spoken) language is difficult, impossible or forbidden. Under such circumstances, people bootstrap communication by means of pantomime and, when these circumstances persist, newly emergent pantomimic communication becomes increasingly languagelike". ${ }^{2}$ Following that way of thinking, one could inquire whether there is a more universal, more communicative, integrative, and commonly comprehensible form of art? The answer is not all that simple. Firstly, even though non-verbal communication seems far less dependent upon culture than that of the verbal, such contextual dependencies are also quite visible there, sometimes even very clearly. One has to realise the extraordinary dissemination, both in time and space, of pantomime elements in a broad sense: regardless of whether it is a Maori war dance, or the changing of the guard at the Indian-Pakistani border, or various forms of Asian theatre benefitting from the codified means of pantomime expression (bunraku, kathali, Chinese opera, xigu theatre, ${ }^{3}$ etc.). The encounter with kudijattam

${ }^{1}$ See Abstract to S. Wacewicz, P. Żywiczyński, Pantomimic Conceptions of Language Origins, in: Handbook of Human Symbolic Evolution, Oxford 2021, DOI: https://doi. org/10.1093/oxfordhb/9780198813781.013.30 (access to all websites included in the paper - 14.06.2021).

2 P. Żywiczyński, S. Wacewicz, C. Lister, Pantomimic fossils in modern human communication, "Philosophical Transactions of the Royal Society B", no. 376(1824)/2020, DOI: https://doi.org/10.1098/rstb.2020.0204, p. 1.

3 It does not mean simply emulating external human behaviour. "A Chinese actor focuses on (...) arousing essential impulses in their body that are the roots of such 
(which in the Malayalam language means a collective play), the oldest and the only form of Indian theatre that has survived almost intact for twenty-five centuries through to current times in the southern state of India called Kerala, can be considered a journey into the far distant past and the difficult to grasp present. The language of gestures used there can convey not only the ideas and meanings of words, but also various grammatical forms (indicate a number, gender or even tense!), as well as to communicate emotions, orders or negation. ${ }^{4} \mathrm{Kat}$ in karate, and its numerous counterparts in other martial arts, can also be considered a form of pantomime. In the case of such non-verbal communication, there is also the ability to feel other people's emotions; foresee their behaviour: "Chi (Qi) movements". An unusual form of pantomime that borders between spontaneous gestures and directed movements is certainly a shamanic dance. Some cultural researchers perceive it as the roots of pantomime as a form of art. ${ }^{5}$

In all the foregoing examples, the message is obviously non-verbal but strongly dependent upon cultural contexts, and to such extent that it may be impossible, or bordering the impossible, for someone from another cultural circle to fully understand it. Even emotions expressed by gestures and facial expressions, referring to the spontaneous, natural reactions of a human body, which can undoubtedly be useful in cross-cultural communication, can also be the source of unintended misunderstandings

behaviours.” M. Steiner, Uczniowie z sadu grusz. O aktorze chińskiego teatru tradycyjnego xigu, in: Actor's presence. Open lectures, curator M. Dziewulska, Warsaw 2008, pp. 69-70.

4 See A. Łopatowska, Kudijattam. Keralski teatr światynny - jedyna forma panindyjskiego teatru klasycznego, in: Actor's presence. Open lectures, curator M. Dziewulska, Warsaw 2008, pp. 111-124. "The eyes of the kundijattam actors are constantly moving in circles, moving in a straight line, horizontally, vertically, or diagonally. The actors draw eights and semicircles with their glances, sometimes at an exorbitant pace. In the old tradition of chakyars, there were as many as 21 eye movement patterns. Today, fewer of them are used." Ibidem, p. 119.

5 The road from shamans and exorcists to actors of the ritual folk theatre was discussed inter alia by Polish sinologist Izabella Łabędzka, Teatr obrzędowy w Chinach, "Scripta Neophilologica Posnaniensia, no. 1/1999, pp. 145-160 and in her book Obrzędowy teatr Dalekiego Wschodu, Poznań 1999. See also E. Rozik, The Roots of Theatre. Rethinking Ritual and Other Theories of Origin, Iowa City 2002, p. 71. A.B. Shankibayeva, G.A. Dauletkulova, S.K. Karzhaubayeva write about Kazakh traditions, Pantomime as a Binding Thread between National Tradition and Modernity, "International Journal of Arts and Humanities", Vol. 1, Issue 9, http://journal-ijah. org/uploads/ijah_01_55.pdf, pp. 765-767. On incorporating animal behaviour into shamanic rituals see M. Pędracki, Szamańska geneza idei odkupienia i ofiary. Wktad Wactawa Sieroszewskiego (1858-1944) do antropologii religii, Opole 2013, p. 45. 
and difficulties. This is especially the case in situations where they are to convey some specific information (they are not simple, biologically determined, expressions of emotions ${ }^{6}$ ) - e.g. the head movements that indicate "yes", "no", and "I don't know" in the Balkans, the rest of Europe, and India.

\section{Integrative Functions of the European Art of Pantomime}

When we try to limit our discussion to the form of art only, complicated definitional, terminological, and genre-based problems arise. Specialists argue about, in particular, the scope of the main term itself. ${ }^{7}$ Although in the minds of the average theatre audience, the issue does not seem particularly complicated; it is simply the art of bodily gestures and facial expressions without the use of words. In the Encyclopaedia of the Polish Theatre under the term pantomime (Greek pantomimos - emulator of everything) we find the following definition: "A kind of theatrical expression conveying the content through gestures, facial expressions and body poses. The term pantomime is used to describe 1 . a full-scale stage form; 2. a solo mime show; 3. an element of a dramatic, ballet, operatic performance, etc.". ${ }^{8}$ It is also not that obvious, as evidenced by, for example, an article by Elżbieta Pastecka Rozprawa z pantomima w balecie [A Discourse with Pantomime in Ballet].${ }^{9}$ The pretext for writing

6 See chapter Biology and Culture as Two Determinants of Nonverbal Communication in a classical work of J. Ruesch, W. Kees, Nonverbal Communication. Notes on the Visual Perception of Human Relations, Berkeley-Los Angeles 1959, pp. 15-25.

7 E.g. Karol Smużniak, an exceptional expert on pantomime theatre in Poland indicates that the term by P. Pavis in Stownik terminów teatralnych, Paris 1996; Polish edition translated, devised and supplemented by S. Świtonka, Wrocław 1998 significantly narrows the definition of pantomime. Referring to a concrete work, Smużniak highlights that the term is broadly present in a number of fields, starting from anthropology to psychology, pedagogy, linguistics and aesthetics Pantomima XX wieku. Kierunki i tendencje, Zielona Góra 2002, p. 203.

8 Encyklopedia teatru polskiego, Małgorzata Bruder as the author of the term http://www.encyklopediateatru.pl/hasla/226/pantomima.

9 E. Pastecka, Rozprawa z pantomima w balecie, “Taniec”, no. 2/2020, pp. 10-13, http://www.irk.org.pl/pdf/taniec.2020.2.pdf. Elżbieta Pastecka, born in 1952 in Warsaw, is a pantomime artist, theatre of movement producer, educator, reviewer, as well as theatre critic. She was also the initiator (as per request of the Polish Centre of the International Theatre Institute) and an artistic director of the International Pantomime Day (1998-2004), during which Polish and international pantomime artists were presented (from the Czech Republic, France, Japan, Germany, Slovakia, Ukraine, and the USA). 
it was the premiere of "Korsarz"10 at the Teatr Wielki $\left(17^{\text {th }}\right.$ September 2020). As a gifted expert on the subject, Pastecka draws attention to the unauthorised (transposed from the nineteenth century) use of the term pantomime which, in the twentieth century, acquired a different meaning and does not only mean expressing words with facial expressions or gestures. The author definitely argues with the careless referring to pas d'action scenes as a pantomime in ballet performances. To make things even more complicated, it can be added that the word pantomime changes its meaning depending on whether it refers to Greek, Latin, English, or French theatre. ${ }^{11}$

Let us leave these definition problems aside. A more important subject to clarify our discussion is space and time - on a macro scale, of course. While summarising these issues synthetically, one must state that the Eastern world has successfully consolidated the significance of pantomime elements in theatre, and, what is more, has, to a great extent, maintained the continuity of its development (with a significant "solidification" of the shape of stage expressions) and the coherence of its language within individual cultural circles. Western art has broken this continuity on numerous occasions, by transferring the art of facial expressions and gestures from the theatre stages to the street, to fairs and markets or circus arenas, occasionally forgetting about the old patterns and customs. It was here, however, that the pantomime developed its autonomous language, earned a separate, distinctive place among the beings of theatrical life although at the cost of assimilating various phenomena and permeating derivative genre forms. A vital stage in the emancipation of pantomime was the activity of the Jacques Copeau Acting School, opened in 1921 at the Theatre of the Vieux-Colombier in Paris. ${ }^{12} \mathrm{~A}$ subsequent, thus essential one, is related to the "apostle of silence" (also called "mime corporel dramatique" as derived from its method) Etienne Decroux, who founded a school in Paris in 1940, and, specifically, with his student, the "poet of gesture" Marcel Marceau (1923-2007) - just after World War II. ${ }^{13}$ It became

10 Ballet in three acts with a prologue and epilogue, Libretto: Manuel Legris and Jean-François Vazelle after George Byron, Jules-Henri Vernoy de Saint-Georges and Joseph Mazilier.

11 A. Krzyżak, Marcel Marceau jako rzecznik mimu wspótczesnego, "Roczniki Kulturoznawcze", no. 2/2018, p. 59.

12 See ibidem, p. 55.

${ }_{13}$ It is worth noticing the clear continuity of the French pantomime tradition from the interwar period: E. Decroux was a graduate of a school located at the Theatre of Vieux-Colombier, and Marceau was Decroux's student. See the continuity in J. Dorcy, A la rencontre de la mime et des mimes. Decroux, Barrault, Marceau, Neuillysur-Seine 1958, pp. 23-101. Marceau's name became a synonym of a mime-actor in 
the art of conscious silence, "which draws its sap from the deep roots of a human being" and "is beyond divisions, races, nations, languages". ${ }^{14} \mathrm{In}$ an interview with Jim Bernhard in the early 1980s, Marceau added: "Mime, like music and dance, crosses borders, national and racial barriers. This is an Aristotelian concept because love and crying in the same second have the same meaning all over the world. (...) A man who cuts off his roots cannot develop. What was in the past, what is happening now gives us an opportunity for development. (...) Education is the key; it is important, against the universal violence, to educate a new, sensitive person who will be able to experience poetry and beauty". ${ }^{15}$ Let us also add the great role of "the art of gesture" in shaping the forms of contemporary avant-garde theatre, which "stems both from the aversion to words manifested by alternative theatre, as well as the tremendous development of experiences in bodily expression". ${ }^{16}$

One can say that the contemporary "emancipated" pantomime, which is more and more diverse in terms of genre forms, artistic language, in ternationalised and recognised all over the world, saturated with elements of other arts, accompanied the processes of European integration in the second half of the 20th century. Does highlighting such a coincidence make any substantive sense? Could the tempestuous development of the "Western" pantomime in the last 70 years have somehow influenced the sense of the continent's civilisation community? Can this form of art have a similar effect in the future? Has this (possible) role been noticed by institutions dealing with the EU's cultural policy? The brevity of the article makes it hard to answer these questions competently and comprehensively.

First, let us pay attention to the basic difficulty in creating a pantomime scenario. ${ }^{17}$ It is addressed to a wider, although still elitist, audience; it remains in international circulation and is, additionally, of multi-ethnic composition, and it must refer to truly commonly known works, events, patterns, topoi, etc. They should be realistically present in the fundamental

the second part of the $20^{\text {th }}$ century. T. Leabhart, Modern and Post-Modern Mime, New York 1989, p. 1. The entire pantomime art is sometimes paradoxically identified with Marceau's school. See P. Bu in term Mime, in: Dictionnaire encyclopédique du théâtre, directeur édit. O. Juillard, Paris 1991, p. 557.

14 M. Marceau's words in: A. Krzyżak, M. Michalik, Poza stowami - Marcela Marceau koncepcja milczenia, "Przestrzenie Teorii", no. 33/2020, p. 99.

15 Quoted after: A. Krzyżak, op.cit., p. 73.

16 M. Semil, E. Wysińska, Stownik wspótczesnego teatru. Twórcy, teatry, teorie, Warsaw 1990, p. 249.

17 See, e.g., a review of M. Kocur, Happy oblivion, https://teatralny.pl/recenzje/ happy-oblivion, 2905.html. 
resources of a given civilisation circle, even if etymologically they come from outside it. Let us for example have a look at the inspirations of the Wrocław Mime Theatre from the so-called period of fiction (1956-1961) in the account of the master himself: "Fascinated by Henry Moore's sculpture, I started working on the etude Labyrinth, and once again the last program of The Prodigal Son was prompted by the series of Baroque prints by Hogarth. The mimodrama about Gilgamesh was based on the old Sumerian epic poetry, The Departure of Faust was an attempt at translating Goethe into the language of pantomime, Wyspiański was certainly behind the program of The November Night's Dream, and the expressionist Wedekind inspired Empress Filissa's Menagerie. What else? - Marivaux, and Hamlet, as well as the chivalrous epic were for me the source of inspiration...". ${ }^{18}$ Inspirations taken from distant places must somehow be "domesticated". Let us have a look at a characteristic example of one of the oldest works of the world literature - an epic from ancient Mesopotamia. Although some echoes of the Epic on Gilgamesh can already be found in Romanesque art, also in Poland (Czerwińsk), the explosion of its culture-shaping role in Europe dates back to the midnineteenth century (from the moment Austen Henry Layard discovered cuneiform tablets), and more precisely from the beginning of the 20th century, when it was translated into several languages and published, thus becoming an inspiration for a number of authors". ${ }^{19}$

As K. Smużniak points out, "let us not be fooled by the direct inspirations of literary works, as these are only the starting point for stage productions". ${ }^{20}$ This was confirmed by Henryk Tomaszewski himself in an interview entitled Gdy stowo staje sie ciatem [When the Word Becomes a Body]: "I rely on literary prototypes, but it will never be a literal translation of literature into the language of gesture and facial expressions; pantomime is not a 'mute' story of a literary work. I trust the associations that are born while reading, and these associations, visions, images consequently

18 Gdy stowo staje sie ciatem, Rita Golębiowska's interview with Henryk Tomaszewski, "Tygodnik Kulturalny", no. 39/1985, http://encyklopediateatru.pl/ artykuly/131154/gdy-slowo-staje-sie-cialem\#. In November of 1956 The Hunchback of Notre-Dame after Victor Hugo and The Overcoat after Nikolai Gogol were presented at the Teatr Polski in Wrocław. See K. Smużniak, Wroctawski Teatr Pantomimy 19561978. Kronika. Dokumentacja, Wrocław 1985, pp. 7-15.

19 It was translated into Hebrew in 1900, into German in 1901, into Polish in 1909 (poet Antoni Lange was the translator, who lived between 1861-1929), into English in 1917, and into Russian in 1919. For the reception of the epic see T. Ziolkowski, Gilgamesh among us. Modern Encounters with the Ancient Epic, Ithaca, New York 2012.

20 K. Smużniak, Teatr milczenia i dramat przemilczeń, Zielona Góra 1996, p. 9. 
decide on the choice of the subject". ${ }^{21}$ Such associations are also created by individual experiences and emotions connected with various social constructs - which also include references to stereotypes (including those related to individual ethnoses). Stefan Niedziałkowski wrote that pantomime is de facto a process of self-identification; the mime works on the principle of a sieve that first lets human sensations pass through, then processes them and finally externalises "using only himself as a vessel". So he himself is at the same time the subject, the idea, and the creator of his work. ${ }^{22}$

\section{Festivals as a Form of Non-verbal Cultural Communication in Europe}

For such an individualised art, confrontations with other artists and audience are of great importance, and they are all done effortlessly since they require no linguistic translations. Festivals have become an effective form of such confrontation. The traditions of modern theatre festivals date back to the interwar period, and their rapid development post World War II stemmed from the need for international rapprochement, stabilisation of cultural life, and the confirmation of fundamental moral values through art - hence it was directly related to the integration processes of the continent which, for political reasons, was limited to the West. ${ }^{23}$ Raymonde Temkine ${ }^{24}$ points out that prior to 1973, only a few such larger events had been held in Berlin, Hamburg, Prague, and Zurich, but post that date their number skyrocketed and "one could count them by dozens". According to her estimates, around 30 such meetings took place at the end of the 1960s, in $1977-120$, nine years later - 220, and in 1989, which was a breakthrough year that ended the division of Europe, over $500 .{ }^{25}$ The alternative theatre movement, in which the participation of the theatre

${ }^{21}$ Gdy stowo staje się ciatem..., op.cit.

22 S. Niedziałkowski, J. Winslow, Świat mimu, translated by E. Pastecka, Warsaw 1998, p. 18 (Beyond the Word. The Word of Mime, Michigan 1993). A book with M. Marceau's foreword.

${ }^{23}$ See term Festiwale teatralne in: M. Semil, E. Wysińska, op.cit., p. 109.

24 Raymonde Temkine (1911-2010), a French theatre critic, who had been writing theatre reviews to prestigious publishers for over 40 years. The author of a significant book about Grotowski's theatre (Lausanne 1968), translated into several European languages.

${ }^{25}$ Dictionnaire encyclopédique du théâtre..., op.cit., p. 328. According to the data of the American International Theatre Institute, in 1979 - 850 of such events were held in 56 countries. M. Semil, E. Wysińska, op.cit., p. 110. See also K. Smużniak, Pantomima $X X$ wieku..., op.cit., p. 6. 
of gestures is significant, played a vital role in that real festival explosion. A separate trend of experimental and artistic meetings emerged ${ }^{26}$ which to this day is a driving force of festival life in Europe. Even famous events with a "mature", stabilised formula are trying to connect with this trend. ${ }^{27}$ One should also remember the incredible diversity of European pantomime forms, hence numerous pantomime performances are regularly presented at, e.g. the Festival of Fools in Amsterdam or as part of the largest cultural festival in the world - in Edinburgh (the Edinburgh Festival).

Peter $\mathrm{Bu}$, a theoretician of pantomime and other theatrical forms, as well as an organiser of festivals, in a summary made from the perspective of 1983 (in the "Mime Journal"), listed the following remarkable mime events around the world: Buenos Aires (1973 and 1976), Biel-Bienne (1974-1975), San Martin (Argentina 1974), Santa Fe (1975), Cologne (1976-1983), London (1976-1982), Bruno (1977), Bergamo (1977), Rosario (Argentina 1977), Strasbourg (1977-1982), Avignon (1977), Utrecht (1978-1981), Toronto (1978), Milwaukee (USA 1978), Budapest (1978-1979), Bonn (1978), Ghent (1978), Florence (1978), Barcelona (1978, 1981, 1982), Paris (1978-1982), Liège (1978), Dijon (1979), Tabarka (Tunisia 1979), Asilah (Morocco 1979), Ivry-sur-Seine and Vitry-sur-Seine (1979), Bratislava (1979), West Berlin (1980), Lille (1980-1982), Freiburg in Breisgau (1981), Vancouver (1981), Treviglio (1981), Naples (19811982), Modena (1982), and Marseille (1982). ${ }^{28}$ Even in such a laconic list it is not difficult to spot the specificity of these events along with, in particular, their ephemeral character. They rarely turn into permanent, cyclical events - and the problem undoubtedly lies in the exclusiveness of this type of art, as well as problems with stable financing. Another distinguishing feature (the sources of which probably lie in the genotype of European pantomime) may be the reluctance to institutional, stable conditions related to a precise location and clearly defined rigors. ${ }^{29}$ Please

${ }^{26}$ In addition to broadly represented trend of commercial and touristic festivals. We have to remember that the word festival comes from French fête - a celebration. See P. Pavis, Dictionnaire du théâtre, Paris 1996, p. 39.

27 Natalie Elain, from 2019 the Director of Théâtre L'Odyssée and Mimos Festival in Périgueux wrote on the occasion of the $38^{\text {th }}$ edition (from 1983) of the event that: "Le Festival de Périgueux poursuit la mise en lumière des Arts du Geste dans leur diversité et interroge l'évolution du mime dans le paysage scénique. Il sera traversé par des propositions novatrices et inclassables, irriguées par des formes allant de la performance à la marionnette, au clown, masqué ou démasqué". https://www.mimos.fr/le-in. Let us add that Peter Bu was the Director of that Festival for many years (from 1987 to 2002).

${ }^{28}$ K. Smużniak, op.cit., pp. 6, 204.

29 Peter Bu in 1991 believed that the lack of subsidies ("les mimes (...) ne reçoivent que rarement des subventions”) and own theatrical places was due to mimes' ea- 
note that none of these festivals is a direct member of the EFA (European Festivals Association), an association that has been active since 1952, and which connects around 100 festivals and their associations from over 40 countries. ${ }^{30}$ And yet, the current EFA authorities see the main goal of their activities in the following manner: "The European Festivals Association's mission is to unite and represent its member festivals across Europe and the world by contributing to the artistic life of Europe. It acts as the most important platform for arts festivals. EFA members take the joint responsibility that the arts are prioritized offering their platforms to bring the arts to the audiences. (...) By supporting and enabling artistic creation, production and participation, EFA and its members ensure that this right is made a reality for all citizens. Interaction between festivals, with public authorities and the other stakeholders in the arts are central to EFA's work".

Mime art festivals appear in the databases of the Europe for Festivals, Festivals for Europe (EFFE) project, initiated by the EFA in 2014 and supported by the European Commission and the European Parliament: "EFFE brings the arts to the attention of festival audiences through a searchable database, FestivalFinder.eu, that serves all sorts of interactions and initiatives recognizing the work of Europe's diverse arts festivals landscape. Europe is in constant development and change. EFFE's strength is in its diversity; its offer to have a discussion about the possibilities to give the arts more space within our societies". ${ }^{31}$ In October 2020, the new platform FestivalFinder.eu (a) Live Now was launched, based on the data and experience of FestivalFinder.eu. The two-year project is co-financed by the EU from the Creative Europe Programme. About 2,300 festivals are currently registered and assumed partnerships with the EFA, City of Bergen, Italiafestival, publiq, Summa Artium, and EURACTIV Media Network. The benefits arising from the project sound encouraging: "FestivalFinder.eu (a)Live Now brings together cities, tourism boards, media partners and academia under a shared objective: to bring local content on arts and arts festivals from various perspectives to the attention of audiences worldwide. Various toolkits will be created for the attention of these different stakeholders". At present, one can find 7 festivals there in the area that interests us the most: the International Mime Festival named after Leonid Engibarov (Yerevan, Armenia), the

gerness to explore and experiment, as well as their resentment to be closed in narrow, institutionalised frames and the lack of developed theoretical mind in this art form. See term Mime in: Dictionnaire encyclopédique du théâtre..., op.cit., p. 558.

${ }^{30}$ https://www.efa-aef.eu/en/about/.

31 https://www.festivalfinder.eu/about. 
Mime Fest (Polička, Czechia), the International Mime Festival Dresden (Germany), the International Puppet \& Mime festival of Kilkis (Kilkis, Greece), the Mime Wave Festival (Kyiv, Ukraine), the international festival of clowns and mimes "Comediada" (Odesa, Ukraine) and the International Mime Art Festival (Warsaw, Poland). The latter festival is credited to the contribution of the already mentioned outstanding mime Stefan Niedziałkowski, ${ }^{32}$ who was its Artistic Director between the years 2000-2004. ${ }^{33}$ In 2020, the 20th edition of the festival took place online (due to the outbreak of the COVID-19 pandemic). Mime theatres from all over the world present the masters of the genre as well as the most diverse forms there: from classical, physical theatre, clowning to new non-classical methods of non-verbal communication. The clash of genres is noticeable during the workshops. It became a proud tradition of the event to create a new performance as part of the Contemporary Pantomime Evening, which is supposed to be a confrontation of various techniques, styles and forms.

Looking at the dossier of the Wrocław Mime Theatre, it might seem that even in the past, in a divided Europe, contacts and exchange of artistic experiences were not hindered. ${ }^{34} \mathrm{~A}$ different picture, however, is painted following the analysis of the materials of the Security Service,

${ }^{32}$ http://www.mimearttheatre.pl/pl_stefan.niedzialkowski.htm.

33 https://www.mimowie.pl. In 2005 Bartłomiej Ostapczuk became the Artistic Director of the International Mime Art Festival.

34 Wrocław Mime Theatre in the West 1958-1968 (based on J. Hera's Henryk Tomaszewski $i$ jego teatr, Warsaw 1983, pp. 97-102): 1958 - England (London); 1961 - West Germany (Selb, Munich, Bad Godesberg, Stuttgart, Wanne-Eickel, Lunden, Recklinghausen); Belgium (Brussels, Liège); France (Paris); Switzerland (Geneva, Montreux); participation in the 1st World Mime Festival in West Berlin; Italy (Milan, Livorno, Reggio Emilia, Rome); 1962 - France (Paris); 1963 - Israel (Tel Aviv, Kiriat Haim, Jerusalem, Nathania, Haifa); Denmark, Sweden and Finland (Oslo, Copenhagen, Aarhus, Stockholm, Lund, Turku, Helsinki); Greece; 1964 - West Germany (Bochum, Solingen, Leverkusen, Bergisch-Gladbach, Düsseldorf, Marl, Essen, Bottrop, Lubeck, Hanover, Hamburg, Herford, Detmold, Bad Godesberg, Dortmund, Cologne); The Netherlands (Enschede, Tilburg, Amersfoort, Amsterdam, Schveningen, Eindhoven, Breda, Nijmegen); 1965 - USA (Springfield, New York, Princeton, Stranford, Hartford, Philadelphia, Washington); Canada (Toronto, Montreal); The Netherlands (Utrecht, The Hague, Nijmegen, Einhoven, Delft, Maastricht, Enschede, Breda, Roermond); West Germany (Solingen, Viersen, Marl, Remascheid, Düsseldorf, Oserlohn, Olpe, Aachen, Essen, Giessen, Hamburg, Hildesheim, Bensberg, Lüdenscheid, Neheim-Hüsten, Wiesenbaden, Munich); Austria (Salzburg); 1966 Scotland (Edinburgh); Denmark (Holstebro, Copenhagen); Sweden (Lund); Italy (Ancona, Bari, Fasano, Aquilla, Turin, Pavia); 1967 - Denmark (Hjøring, Holstebro, Aalborg, Odense, Copenhagen); Sweden (Malmö, Goteborg, Karlstad, Eskilstuna, Stockholm); 1968 - Italy (Milan). 
which, especially until the beginning of the 1970s, strongly invigilated the theatre environment (including M. Marceau himself), controlled departures of individual persons and demanded cooperation in exchange for passports, ${ }^{35}$ Let us also pay attention to the fact that the prestigious London International Mime Festival, which took place from 1977 until the collapse of the Berlin Wall, only on one occasion hosted a group from Poland in its repertoire (the Warsaw Mime Theatre in 1985), but from the Eastern Bloc there were also artists from Bulgaria (1980) and Czechoslovakia (1979, 1980, 1981, 1982, 1988).

What is also surprising is the fact that in the above list based on FestivalFinder.eu (a)Live Now there are no festivals from Western Europe - the platform, at least with regards to pantomime, is primarily used to integrate the cultural life of the East into the common European circle. It is understandable, however, that we will not find a whole bunch of "off" and "off-off" events there. Peter Bu points out that the representatives of the theatre of gesture often do not want to leave the specific margin of theatrical life to institutionalise and formalise their artistic exploration. The significant role of this trend in the development of modern culture and its dissemination lies in exploration and crossing the boundaries (towards inter alia the art of dancing, and the theatre of the word). ${ }^{36}$ In order to illustrate this phenomenon and the circumstances related thereto, let us refer to the AKT Theatre in Warsaw.

The theatre was founded by graduates of Mime Study [Studium Pantomimy] (under the supervision of Jerzy Winnicki ${ }^{37}$ ), and established at the Ester Rachel and Ida Kamińska Jewish Theatre in 1987 under the management of Jerzy Szurmiej. ${ }^{38}$ Since 1991, it has been operating as the AKT Theatre Association. It was derived from the Polish pantomime

35 S. Ligarski, Agentura we Wroctawskim Teatrze Pantomimy in: Aparat Represji w Polsce Ludowej 1944-1989, Warszawa 2009, pp. 225-251.

${ }^{36} \mathrm{P}$. Bu in term Mime in: Dictionnaire encyclopédique du théâtre..., op.cit., p. 558.

37 Jerzy Winnicki, born in 1943, a mime and drama actor - connected with the Laboratory Theatre of 13 Rows, the Student Pantomime Theatre GEST, and later with the Jewish Theatre, Warsaw Art Centre "Studio", the National Theatre and the Warsaw Chamber Opera. At the same time, let us not forget about the 35 years of prolific activity of the Student Pantomime Theatre GEST from Wrocław: during this time, he prepared 12 premieres, produced several dozen etudes as well as studio programs, and received numerous awards in Poland as well as abroad (e.g. at the following festivals: in Nancy, Leeds, Istanbul, Wrocław, Kraków, Toruń), and performed in France, Finland, Sweden, Great Britain and Turkey, etc.

38 The Theatre Association of the Theatre of Movement Akt was originally created by: Agnieszka Musiałowicz, Marek Kowalski and Tomasz Musiałowicz, who are in the group to this day. They were later joined by Marta Suzin, Tomasz Dusiewicz, Janusz Porębski and Krzysztof Skarżyński. 
school tradition, but very quickly began to develop its own artistic language. Street and outdoor experiences (initially due to the lack of a theatre stage), which drew from the traditions of itinerant comedians, fairground theatres, circus and commedia dell'arte, forced the actors to constantly diversify their means of expression. The art of mime, gesture, and visual image still dominate, however, it is complemented with circus and dance elements, as well as all kinds of acrobatics.

The Akt Theatre is not a repertoire theatre, it consistently adheres to its original, independent form. It often represents Warsaw at street theatre festivals in Poland and abroad. Stage and outdoor performances, street parades, fire shows, as well as specially-prepared art projects are presented in a number of places in Europe (in Germany, Slovenia, Belgium, Sweden, Czech Republic, Russia, Italy, Austria, Croatia, Lithuania, Belarus, and Ukraine) and Asia (China, Japan, Israel, Saudi Arabia, and Turkey). The trip to the island of Stromboli for the 2009 Teatro del Fuoco Festival turned out to be particularly prolific, which enabled close contact with artists from all over the world to be established and then led to participation in subsequent inspiring theatrical adventures. ${ }^{39}$

The performance offer is rather diverse: Perperuna is a journey to Slavic roots (the myth of Perun - the god of fire), Leviathan transposes the biblical legend about a monster that brings misfortune to the modern times (Golden Mask at the International Street Theatre Festival in Chojnice'96), The Steadfast Tin Soldier refers to the famous fairy tale by J.Ch. Andersen (Culture Foundation's award at the Theatrical Festival Valise - Łomża 2000), Phoenix is a story about nature and civilisation and the clash thereof, which takes place inside every human being (Grand Prix of the 10th Theatre Festival Dionizje'2002), the spectacular Icarus, co-produced with a group of avid paragliders and balloonists from Torun (Falco Group), who transposed into our times the Greek myth of an incurable dreamer, ${ }^{40}$ Planet of Roses inspired by Antoine de SaintExupéry's The Little Prince, The Flowers of Evil referring to the poetry of Charles Baudelaire, etc. What is also quite characteristic is the fact that Chick-Stick - a light, humorous performance is most often invited to festivals both in Poland and in Europe. In 2004, the Akt Theatre, in collaboration with the city of Warsaw, organised the first edition of the

39 Performances in Lipari, Vulcano, Favignana, as well as in Palermo and Rome during a grand national gala.

40 The performance was also presented in the courtyard of the University of Warsaw on $6^{\text {th }}$ June 2014 at the invitation of the Centre for Europe of the University of Warsaw. On $10^{\text {th }}$ October of this year, the premiere of Beyond Time took place there (in the so-called small courtyard). 
Czarna Offca Festival - a Warsaw theatre offensive. The festival aims at presenting the activity of independent Warsaw theatre groups in a single series. From that date onwards, the event went on to become a permanent fixture in the calendar of Warsaw cultural events. ${ }^{41}$

\section{Conclusions}

It is difficult to maintain this kind of activity within the "official" institutionalised mainstream of theatrical life, but it can, however, be supported, even from EU sectoral support finances (e.g. from the Creative Europe Programme ${ }^{42}$ ) albeit the EU has no harmonisation competences in the culture area, but solely complementary and supplementary ones to Member State activities. The EU's cultural policy is suspended between the competences of the Member States and those of the European Union, which should not, however, hinder its impact on national cultural matters - although the application of the subsidiarity principle here seems controversial, and high-level negotiations of these kind of EU programmes "result in the poor identification of local and regional cultural institutions [with them]"43. Devoting more attention to such institutions (or rather cultural areas, such as theatre events, confrontations, meetings or festivals, which are, often spontaneously, organised) gives real meaning to the EU slogan "United in diversity", which is often criticised for the lack of specific content - as highlighted by Dorota Jurkiewicz-Eckert. ${ }^{44}$ In this context, one has no choice but to admit that the author's final postulate is also on point: "EU cultural policy cannot focus on flagship

${ }^{41}$ All information based on oral relations from the group members (Spring 2021).

42 The European Commission's documentary entitled Overview of the Creative Europe Calls for Proposals 2021: Culture strand:

"1.2 European platforms for the promotion of emerging artists

This action will support projects that will aim at increasing the visibility and the circulation of European emerging artists and works outside their own borders, in Europe and beyond, and at increasing cultural access to and participation in culture as well as audience engagement and development. Such projects are also meant to contribute to the implementation of EU policy priorities in the culture field. In this regard, the circulation of artists and works can contribute to the activation of new and/or more sustainable cultural public spaces". https:/ec.europa.eu/culture/document/overview-creative-europe-calls-proposals-2021-culture-strand.

43 See B. Gierat-Bieroń, Polityka kulturalna Unii Europejskiej, Kraków 2018, pp. 223-228.

${ }_{44}$ D. Jurkiewicz-Eckert, Od Traktatu o Unii Europejskiej do Europejskiej Agendy dla Kultury - narodziny i rozwój polityki kulturalnej UE, "Studia Europejskie”, no. 1/2015, p. 65 . 
programs, the rhetoric of creativity and the economy of culture. The area where culture requires European Community's support is substantially broad". ${ }^{45}$ One may hope for a better understanding of the role of such local (and at the same time crucial for international cultural exchange) projects following Commissioner Maria Gabriel's statement with regards to a meeting with EFA representatives on $22^{\text {nd }}$ June 2021: "Festivals are an important driver of local and regional development, contributing immensely to social cohesion across generations. (...) In this particular time, we need festivals to reach citizens and engage with them on their wishes and ideas for European integration". ${ }^{46}$

Undoubtedly, with regard to the foregoing multi-coloured festival movement of mime theatres, street theatres, etc., direct support depends on the budgets of regions, local governments, regional and local cultural institutions, etc., which became especially significant in connection with the COVID-19 pandemic. ${ }^{47}$

One has to remember how diverse and decentralised the world of pantomime and street art is. Characteristic is the fact that an attempt to unite European creators under the banner of the European Mime Federation, which was undertaken shortly after the demolition of the Wall in January 1991, at the initiative of the Dutch Mime Centre and two outstanding mimes Yves Marc and his wife Claire Heggen (Etienne Decroux's students) as an attempt to promote international collaboration and to create an information exchange centre was a failure. ${ }^{48}$ The first meeting took

45 Ibidem, p. 87.

46 https://www.efa-aef.eu/en/news/2027-arts-festivals-reconfirm-their-vital-contribution-for-europe-with-mariya-gabriel-eu-commissioner/.

47 For example, the international mime festival Mimos in Périgueux is co-financed by the city of Périgueux, Direction régionale des affaires culturelles (DRAC) de Nouvelle-Aquitaine, the Nouvelle-Aquitaine region and the Dordogne and Communauté de l'Agglomération Grand Périgueux department (an association of $43 \mathrm{com}$ munes, inhabited by over 100,000 residents). But, for example, the International Festival of Avant-garde Theatres and Culture PESTKA (Jelenia Góra) is part of the "Together into the Future" project financed by the European Union under the Operational Program for Regional Development INTERREG Poland - Saxony and the Czech Republic - the Republic of Poland 2014-2020. https://www.festivalpestka.pl/ kopia-pestka-2019

48 E. Pastecka, Pantomima wobronie wtasnej, “Taniec”, no. 3-4/1992, p. 38. Elżbieta Pastecka and Andrzej Szczużewski were the Polish representatives who took part in the initiative. Andrzej Szczużewski was an actor at the Wrocław Mime Theatre in the years 1959-1975, and in 1975-1982 was the initiator, co-creator, and an actor of the Mime Stage at the Warsaw Chamber Opera. Later in his life he lectured on pantomime techniques and movement improvisation in the USA, including at Yale University. In 1985, he established the Berlin Mime Company. 
place in September in Amsterdam with the participation of about 60 people from fifteen countries, including the USA and Canada, ${ }^{49}$ the second was held in May 1993 and was devoted to European creators (Etienne Decroux, Oskar Schleman, Vsevolod Meyerhold); it gathered over 120 participants from Europe, Canada, and the USA. The initiative did not, however, withstand the test of time. Hence, more and more initiatives have been undertaken, but so far without any spectacular results.

In 2013, the Federation of European Mime (FEM) was created, which was founded by representatives of three educational centres of pantomime theatre: Nils-Zdenek Kühn (Die Etage Berlin - Department Pantomime/ Physical Theatre), Bartłomiej Ostapczuk (Warsaw Pantomime Centre) and Adam Halaš (HAMU Praha - Department Nonverbal Theatre). The association supports and popularises the European art of pantomime, and provides education to artists and teachers of pantomime theatre. It organises the annual MY MIME festival (Berlin 2014, Prague 2015, Warsaw 2016, Saint Petersburg 2017, Liptovský Mikuláš 2018), as well as conferences and an international exchange. ${ }^{50}$

In 1998, during a tour by mimic artist Ofer Blum around the then Yugoslavia (organised by Marko Stojanovič, a friend from M. Marceau's school), the idea of the World Mime Organization and World Mime Day were born. In 2004, the WMO was officially registered as a non-profit NGO in Serbia, and since 2011 the World Mime Day has been celebrated (as a continuation of Jean Bernard Laclotte's idea), which was finally set for $22^{\text {nd }}$ March - M. Marceau's date of birth. In 2019, the second World Mime Conference connected with the International Monodrama and Mime Festival in Belgrade took place. In 2017, the WMO became an official partner of the International Theatre Institute (ITI-UNESCO). The in statu nascendi organisation attempts at developing diverse forms of activity, although the results are yet to be seen. ${ }^{51}$

The abovementioned observations have already highlighted the integrative role of the École Internationale de Mimdrame in Paris, founded in 1978 by M. Marceau. To some extent, this role has also been played by specialist journals, in particular the "Mime Journal" (a yearly, launched in 1974, publishing texts "on Decroux corporal mime and mimerelated modern movement forms"), "Mimekrant" (published in French and Flemish by Mime Centre of Flanders) and Spanish "Movimento"

49 http://totaltheatre.org.uk/archive/features/report-european-mime-federation, (access 14.06.2021), E. Pastecka gives slightly different numbers: 70 people from 13 countries.

${ }^{50}$ https://www.mimefederation.eu.

51 Information from the WMO's website: http://www.worldmime.org. 
(since 1979 edited by Victor Hernando of the Centro de Investigaciones del Mimo in Buenos Aires). ${ }^{52}$

Irrespective of the foregoing activities, the discussed trend of nonverbal cultural message in Europe is still poorly integrated, maintaining the extraordinary variety of genres and multi-colour forms. One can say that in the dispersion, in the characteristic decentralisation, there lies also its strength, which is manifested by an easiness in reaching out to a highly diverse audience (an audience, incidentally, that would never come to an institutional theatre), the ability to receive feedback from mass audiences, expansiveness (taking up various spaces), a flexible approach in quest for answers - but at the same time respecting the elements of the rich, native European tradition of popular culture..$^{53}$

\section{References}

Dictionnaire encyclopédique du théâtre, directeur édit. O. Juillard, Paris 1991.

Dorcy J., A la rencontre de la mime et des mimes. Decroux, Barrault, Marceau, Neuilly-sur-Seine 1958.

Encyklopedia teatru polskiego, http://www.encyklopediateatru.pl/hasla/226/ pantomima.

Gdy stowo staje sie ciatem, wywiad z H. Tomaszewskim przeprowadzony przez R. Gołębiowską, „Tygodnik Kulturalny”, no. 39/1985 (29.09), http://encyklopediateatru.pl/artykuly/131154/gdy-slowo-staje-siecialem\#.

Gierat-Bieroń B., Polityka kulturalna Unii Europejskiej, Wydawnictwo Uniwersytetu Jagiellońskiego, Kraków 2018.

Hera J., Henryk Tomaszewski i jego teatr, Państwowy Instytut Wydawniczy, Warszawa 1983.

http://totaltheatre.org.uk/archive/features/report-european-mimefederation (access 14.06.2021).

http://www.mimearttheatre.pl/pl_stefan.niedzialkowski.htm (access 14.06.2021).

http://www.worldmime.org (access 14.06.2021).

52 See A. Lust, Bringing the Body to the Stage and Screen: Expressive Movement for Performers, Lanham-Toronto-Plymouth UK 2012, pp. 308-309.

${ }_{53}$ About commedia dell'arte, pantomime and theatre relations in English tradition see J. O'Brien, Harlequin Britain. Pantomime and Entertainment 1690-1760, BaltimoreLondon 2004, chapter 2: Pantomime, Popular Culture and Invention of English Stage, pp. 30-59. About the diversity of the European types of commedia dell'arte see A. Nicoll, W świecie arlekina. Studium o komedii dell'arte itical, Warsaw 1967, pp. 163-166. 
https://ec.europa.eu/culture/document/overview-creative-europe-callsproposals-2021-culture-strand (access 14.06.2021).

https://teatralny.pl/recenzje/happy-oblivion,2905.html (access 14.06.2021). https://www.efa-aef.eu/en/about/ (access 14.06.2021).

https://www.efa-aef.eu/en/news/2027-arts-festivals-reconfirm-theirvital-contribution-for-europe-with-mariya-gabriel-eu-commissioner/ (access 14.06.2021).

https://www.festivalfinder.eu/about (access 14.06.2021).

https://www.festivalpestka.pl/kopia-pestka-2019 (access 14.06.2021).

https://www.mimefederation.eu (access 14.06.2021).

https://www.mimos.fr/le-in (access 14.06.2021).

https://www.mimowie.pl (access 14.06.2021).

Jurkiewicz-Eckert D., Od Traktatu o Unii Europejskiej do Europejskiej Agendy dla Kultury - narodziny i rozwój polityki kulturalnej UE, „Studia Europejskie", no. 1/2015.

Krzyżak A., Marcel Marceau jako rzecznik mimu wspótczesnego, „Roczniki Kulturoznawcze”, no. 2/2018, DOI: https://doi.org/10.18290/ rkult.2018.9.2-4.

Krzyżak A., Michalik M., Poza stowami - Marcela Marceau koncepcja milczenia, „Przestrzenie Teorii”, no. 33/2020, DOI: https://doi. org/10.14746/pt.2020.33.4.

Leabhart T., Modern and Post-Modern Mime, Macmillan Education, New York 1989, DOI: https://doi.org/10.1007/978-1-349-20192-1.

Ligarski S., Agentura we Wroctawskim Teatrze Pantomimy, in: Aparat Represji w Polsce Ludowej 1944-1989, IPN, Warszawa 2009.

Lust A., Bringing the Body to the Stage and Screen: Expressive Movement for Performers, The Scarecrow Press Inc., Lanham-Toronto-Plymouth UK 2012.

Łabędzka I., Obrzędowy teatr Dalekiego Wschodu, Wydawnictwo Naukowe UAM, Poznań 1999.

Łopatowska A., Kudijattam. Keralski teatr światynny - jedyna forma panindyjskiego teatru klasycznego, in: Obecność aktora. Wyktady otwarte, kurator M. Dziewulska, Teatr Narodowy, Warszawa 2008.

Nicoll A., $W$ świecie arlekina. Studium o komedii dell'arte, Państwowy Instytut Wydawniczy, Warszawa 1967.

Niedziałkowski S., Winslow J., Świat mimu, Wydawnictwa Szkolne i Pedagogiczne, Warszawa 1998.

O'Brien J., Harlequin Britain. Pantomime and Entertainment 1690-1760, John Hopkins University Press, Baltimore-London 2004.

Pastecka E., Pantomima w obronie wtasnej, „Taniec”, no. 3-4/1992. 
Pastecka E., Rozprawa z pantomima w balecie, „Taniec”, no. 2/2020, http:// www.irk.org.pl/pdf/taniec.2020.2.pdf.

Pavis P., Dictionnaire du théâtre, Dunod, Paris 1996.

Pavis P., Stownik terminów teatralnych, Zakład Narodowy im. Ossolińskich, Wrocław 1998.

Pędracki M., Szamańska geneza idei odkupienia i ofiary. Wktad Wactawa Sieroszewskiego (1858-1944) do antropologii religii, Wydawnictwo Naukowe Scriptorium, Opole 2013.

Rozik E., The Roots of Theatre. Rethinking Ritual and Other Theories of Origin, University of Iowa Press, Iowa City 2002.

Ruesch J., Kees W., Nonverbal Communication. Notes on the Visual Perception of Human Relations, Univerity of California Press, Berkeley-Los Angeles 1956.

Semil M., Wysińska E., Stownik wspótczesnego teatru. Twórcy, teatry, teorie, Wydawnictwo Artystyczne i Filmowe, Warszawa 1990.

Shankibayeva A.B., Dauletkulova G.A., Karzhaubayeva S.K., Pantomime as a Binding Thread between National Tradition and Modernity, „International Journal of Arts and Humanities”, Vol. 1, Issue 9, http:// journal-ijah.org/uploads/ijah_01_55.pdf.

Smużniak K., Pantomima XX $\overline{w i e k u}$. Kierunki i tendencje, Uniwersytet Zielonogórski, Zielona Góra 2002.

Smużniak K., Teatr milczenia $i$ dramat przemilczeń, Uniwersytet Zielonogórski, Zielona Góra 1996.

Smużniak K., Wroctawski Teatr Pantomimy 1956-1978. Kronika. Dokumentacja, Wydawnictwo Uniwersytetu Wrocławskiego, Wrocław 1985.

Steiner M., Uczniowie z sadu grusz. O aktorze chińskiego teatru tradycyjnego xigu, in: Obecność aktora. Wyktady otwarte, kurator M. Dziewulska, Teatr Narodowy, Warszawa 2008.

Wacewicz S., Żywiczyński P., Pantomimic conceptions of language origins, „Handbook of Human Symbolic Evolution”. Oxford University Press, April 2021, DOI: https://doi.org/10.1093/oxfordhb/97801988 13781.013.30.

Ziolkowski T., Gilgamesh among us. Modern Encounters with the Ancient Epic, Ithaca, New York 2012, DOI: https://doi.org/10.7591/ cornell/9780801450358.001.0001.

Żywiczyński P., Wacewicz S., Lister C., Pantomimic fossils in modern human communication, „Philosophical Transactions of the Royal Society B”, no. 376(1824), DOI: https://doi.org/10.1098/rstb.2020.0204. 